\title{
PEMANFAATAN LIMBAH PERTANIAN TANAMAN PANGAN SEBAGAI PAKAN TERNAK RUMINANSIA DI KECAMATAN LOLONG GUBA KABUPATEN BURU
}

\author{
Dominggus de Lima, C. Ch. E. Latupeirissa* \\ Jurusan Peternakan, Fakultas Pertanian, Universitas Pattimura \\ Jl. Ir.M. Putuhena, Kampus Poka, Ambon 97233 \\ *Email : dominggus.delima@faperta.unpatti.ac.id
}

\begin{abstract}
ABSTRAK
Penelitian ini bertujuan untuk mengetahui jenis limbah pertanian, pemanfaatan limbah sebagai pakan ternak ruminansia, dan pengetahuan peternak mengenai pengolahan limbah pertanian. Penelitian ini dilakukan menggunakan metode survey serta observasi langsung di lapangan. Teknik pengambilan sampel dilakukan secara purposive sampling yaitu diambil tiga desa (Desa Waegeren, Grandeng dan Wanakarta) berdasarkan jumlah petani peternak terbanyak dan diambil 30 peternak. Hasil penelitian penelitian menunjukkan usaha peternakan merupakan usaha sampingan $100 \%$. Sumber pakan pokok untuk ternak, biasanya diberikan rumput lapangan $100 \%$ dan sebagai pakan tambahan yaitu rumput unggul $66,67 \%$. Umumnya menggunakan limbah pertanian digunakan sebagai pakan sampingan selain hijauan pada padang penggembalaan, pemberian limbah tergantung pada musim panen. Limbah pertanian yang digunakan sebagai pakan adalah jerami jagung 16,6 \%, jerami padi 43,33\%, jerami ketela pohon 6,6 \% dan jerami ketela rambat 33,3\%. Hasil penelitian dapat disimpulkan bahwa peternak menggunakan limbah pertanian yang cukup baik sehingga limbah pertanian tidak terbuang dan menghasilkan keuntungan. Biasanya penggunaan limbah, setelah panen tanpa melalui pengolahan. Berkaitan dengan pengolahan pakan limbah pertanian sangat rendah.
\end{abstract}

Kata kunci: Limbah pertanian, pakan ternak, ruminansia

\section{UTILIZATION OF AGRICULTURAL WASTE AS RUMINANTS FEED IN LOLONG GUBA DISTRICT BURU REGENCY}

\begin{abstract}
The purpose of the research was to find out how many kinds of agricultural waste, the percentage of waste utilization by farmers as feed and the farmers knowledge about the processing of agricultural waste. The method used in the research was survey and observation directly in the location of agricultural crops. The technique used to take the sample was purposive sampling, with which 3 villages were taken (Waegeren, Grandeng and Wanakarta) based on the highest number of farmers and 30 farmers were taken. The result showed that farm business were 100 $\%$ side business. Therefore cattle maintenance and the maintenance management were not fully being noticed by the farmers. These were affect the development of farm business. Source of the main feed were field grass $(100 \%)$ and half of alternative feed were the superior grass $(66.67 \%)$. It was cause by the aviability of field grass which is more easier to get, while the superior grass must go through the planting process so it required longer time to spent, whereas almost all of the farmer's time were spent in farming. Beside forage in pastures, generally agricultural waste also used as the alternative feed and the distribution of the waste depens on the harvest season. Kind of agricultural waste which used as feed were corn straw $(16,6 \%)$, rice straw $(43,33 \%)$, cassava straw $(6,6 \%)$, and sweet potato straw $(33,3 \%)$. Therefore, it can be concluded that the utilization of agricultural waste was good enough, so that it is not wasted and make a good profit. The utilization of agricultural waste for cattle as feed was $93,3 \%$ distribute directly after the harvest without processing.
\end{abstract}

Key word: Agricultural waste, feed, ruminants

\section{PENDAHULUAN}

Usaha produksi peternakan sangat tergantung pada ketersediaan bahan pakan. Aspek kuantitas maupun kualitas pakan harus terjamin, karena dengan hal itu berarti produktivitas peternakan dapat ditingkatkan bila pakan diberikan secara optimal untuk memenuhi kebutuhan ternak (Bodhi dkk., 2017). Salah satu faktor penting dalam pemeliharaan dan upaya peningkatan produktivitas ternak ruminansia adalah hijauan pakan. Hijauan merupakan sumber pakan untuk ternak ruminansia, sehingga untuk 
meningkatkan produksinya harus diikuti dengan peningkatan penyediaan hijauan pakan yang cukup baik dalam kualitas maupun kuantitas. Ketersedian dan kualitas pakan sangat penting mengingat lebih dari 50 $\%$ biaya produksi suatu usaha peternakan digunakan untuk biaya pakan (Parakkasi, 1999).

Faktor penghambat ketersediaan pakan diantaranya adalah semakin berkurangnya areal tanam akibat lahan yang semakin sempit dimana banyaknya pemenuhan kebutuhan lahan bagi pemungkiman dan sarana jalan sehingga perlu berusaha mencari alternatif lain untuk memenuhi kebutuhan pakan ternak ruminansia seperti sapi (de Lima. 2012). Selain itu menurut Sari dkk. (2016), produksi hijauan pakan di suatu lahan atau daerah juga ditentukan oleh faktor iklim terutama curah hujan. Pemanfaatan lahan sebagai daya dukung untuk penggembangan potensi peternakan sudah kurang karena masyarakat tidak begitu memahami pemanfaatan lahan untuk meningkatkan produksi ternak. Salah satu alternatif dalam memenuhi kebutuhan pakan ternak ruminansia adalah dengan pemanfaatan limbah pertanian, dimana limbah pertanian banyak terdapat di daerah pedesaan. Menurut Haryanto (2009), integrasi antara tanaman pangan dengan ternak merupakan suatu alternatif untuk meningkatkan populasi ternak dan dapat dioptimalkan penggunannya sebagai pakan ternak.

Penggunaan bahan pakan alternatif sebaiknya mempertimbangkan beberapa hal, antara lain bahan pakan tersebut tersedia dalam jumlah yang banyak, sehingga untuk memperolehnya tidak perlu mengeluarkan biaya yang besar. Permasalahan umum dalam peningkatan ternak ruminansia ditingkat peternak adalah produksi dan produktivitas masih rendah. Menurut Sitindaon (2013), cara pemeliharaan ternak pada daerah pedesaan masih banyak berdasarkan turun temurun secara tradisional dengan jumlah kepemilikan ternak masih rendah berkisar 1-3 ekor, dan dikelola sebagai usaha sambilan atau tabungan. Dalam peningkatan produktivitas ternak adalah sulitnya menyediakan pakan secara berkesinambungan baik jumlah maupun kualitas. Faktor penting yang harus diperhatikan dalam peningkatan produktivitas ternak adalah ketersedian pakan yang mencukupi secara kualitas dan kuantitas. Rauf \& Rasbawati (2015), terkait dengan penggembangan pakan ternak, diarahkan untuk dapat mengoptimalkan pemanfaatan bahan baku pakan lokal. Pemanfaatan limbah pertanian sebagai pakan alternatif adalah salah satu solusi penyediaan pakan untuk usaha pengembangan ternak sapi potong, karena petani umumnya membakar limbah tanaman pangan agar secepatnya dapat dilakukan pengolahan tanah.

Kecamatan Lolong Guba memiliki potensi pengembangan ternak yang sangat besar, hal ini didukung oleh sumber daya lokal yang tinggi. Sitindaon (2013), sumber daya lokal yang dapat dimanfaatkan sebagai pakan ternak adalah limbah pertanian tanaman pangan. Limbah pertanian dapat menghasilkan bahan kering sebagai bahan pakan sumber energi ternak ruminansia. Kecamatan Lolong Guba kabupaten Buru memiliki populasi ternak ruminansia (sapi, kerbau dan kambing) sebanyak 5.014,6 UT yang tersebar pada 10 desa dan diusahakan oleh 727 peternak. Pekerjaan utama masyarakat di Kecamatan Lolong Guba, sebagian besar berprofesi sebagai petani. Luas lahan pertanian di Kecamatan Lolong Guba adalah 1.497 ha yang terdiri dari : lahan Jagung 30 ha, kacang tanah $20 \mathrm{Ha}$, ubi kayu 30 ha, dan ubi jalar 40 ha., serta terdapat lahan sawah seluas 1.377 ha ((BPS Kabupaten Buru, 2017). Dengan demikian terdapat limbah pertanian berupa jerami padi, jerami jagung, jerami ubi kayu dan jerami ubi jalar yang berpotensi dijadikan sebagai pakan ruminansia.

Penelitian ini dilaksanakan bertujuan untuk mengetahui ketersediaan limbah pertanian, persentase penggunaan limbah pertanian, dan penggunaan teknologi pengolahan limbah pertanian untuk dimanfaakan sebagai pakan ternak ruminansia. Hal ini penting untuk memperoleh data dasar yang berguna sebagai informasi bagi pengembangan ternak ruminansia. Dengan adanya informasi ini diharapkan dapat dilakukan upaya-upaya untuk mengoptimalkan pemanfaatan limbah pertanian sebagai bahan pakan yang dapat memenuhi standart kebutuhan ternak ruminansia.

\section{BAHAN DAN METODE}

Penelitian dilaksanakan di Kecamatan Lolong Guba Kabupaten Buru, dan berlangsung selama tiga (3) bulan. Pertimbangan pemilihan lokasi ini karena kecamatan ini merupakan salah satu sentral pengembangan ternak ruminansia terutama sapi potong di Kabupaten Buru. Berdasarkan data BPS Kabupaten Buru, jumlah ternak ruminansia di Kecamatan Lolong Guba sebesar 5.014,6 UT. Di samping itu terdapat luas panen pertanian tanaman pangan (padi sawah, jagung, ketela kayu dan ubi jalar) sebesar 1.497 ha, potensial untuk menghasilkan limbah pertanian yang dapat dimanfaatkan sebagai pakan ternak ruminansia terutama pada musim kemarau.

Metode yang digunakan adalah metode survey serta observasi langsung di lokasi pertanian tanaman pangan. Teknik pengambilan sampel dilakukan secara purposive sampling dimana diambil 3 desa dari 10 desa, dengan pertimbangan semua desa mempunyai peluang yang sama untuk beternak ternak ruminansia (sapi, kerbau dan kambing) dan mengusahakan tanaman pangan. Data yang dikumpulkan dibedakan atas data primer dan dan sekunder. Data primer diperoleh secara langsung di lapangan dengan metode survey menggunakan daftar pertanyaan. Data Sekunder diperoleh dari Badan Pusat Statistik Kabupaten Buru dan Kecamatan Lolong Guba.

Peubah yang diamati meliputi identitas peternak, aspek usaha peternakan, populasi ternak ruminasia, luas panen tanaman pangan untuk pakan 
ternak ruminansia, dan pemanfaatan limbah pertanian tanaman pangan. Secara rinci peubah pengamatan dapat dijelaskan sebagai berikut : (1) identitas responden (meliputi: umur, jenis kelamin, pendidikan formnal, pendidikan non formal dan pekerjaan) ; (2) aspek usaha peternakan (meliputi: tujuan usaha, kepemilikan kandang, fungsi kandang, sistem pemeliharaan, lama usaha peternak, jenis ternak dan jumlah ternak); (3) pakan ternak ruminansia (meliputi: hijauan yang diberikan, sumber pakan, tempat penggembalaan, pakan tambahan, kepemilikan lahan, tempat usaha pertanian tanaman pangan dan luas lahan) ; dan (4) pemanfaatan jenis limbah pertanian sebagai pakan ternak (meliputi: penggunaan limbah, jenis limbah pertanian, cara pengolahan limbah, mengetahui tingkat pengolahan dan waktu pemberiaan).

Data yang terkumpul, kemudian dilakukan pengolahan data dengan metode analisis statistik deskriptif, dengan jalan menghitung nilai persentase masing-masing peubah pengamatan disesuaikan dengan tujuan penelitian.

\section{HASIL DAN PEMBAHASAN}

\section{Identitas Responden}

Hasil survey terhadap identitas responden di Kecamatan Lolong Guba Kabupaten Buru pada tiga desa sampel yaitu Waegeren, Grandeng dan Desa Wanakarta, menunjukkan $90 \%$ peternak berada pada kategori umur 16- 60 tahun, dan $10 \%$ peternak berada pada umur lebih dari 60 tahun (Tabel 1). Persentase peternak yang berada pada umur 16-60 tahun lebih tinggi dibandingkan peternak yang berumur lebih dari 60 Tahun. Faktor umur identik dengan produktifitas kerja, dimana jika seseorang masih tergolong usia produktif, ada kecenderung produktivitasnya juga tinggi. Sumarsono (2003), bahwa penduduk dalam kelompok umur 16- 60 tahun, terutama laki-laki, umumnya dituntut untuk aktif mencari nafkah. Sedangkan penduduk di atas 60 tahun kemampuan dalam bekerja sudah menurun. Hartono (2005), tenaga kerja yang memiliki umur masih muda cenderung memiliki fisik yang lebih kuat, sehingga diharapkan dapat bekerja keras dibandingkan dengan tenaga kerja yang memiliki usia yang lebih tua.

Peternak pada umumnya berjenis kelamin lakilaki $80 \%$, dibandingkan dengan perempuan yang hanya berjumlah $20 \%$ (Tabel 1). Menandakan bahwa hampir semua laki-laki yang telah mencapai usia kerja terlibat dalam kegiatan ekonomi, karena laki-laki merupakan tulang punggung keluarga. Simanjuntak (2001), tingkat partisipasi kerja laki-laki selalu lebih tinggi dari tingkat partisipasi kerja perempuan karena laki-laki dianggap pencari nafkah yang utama bagi keluarga.

Tabel 1. Identifikasi Peternak Responden Di Kecamatan Lolong Guba

\begin{tabular}{|c|c|c|c|c|c|}
\hline \multirow{2}{*}{ No } & \multirow{2}{*}{ Uraian } & \multicolumn{3}{|c|}{ Desa } & \multirow[b]{2}{*}{ Kecamatan Lolong Guba } \\
\hline & & Waegeren & Grandeng & Wanakarta & \\
\hline \multirow[t]{3}{*}{1.} & Umur (\%) & & & & \\
\hline & a. $16-60$ & 30,00 & 33,33 & 26,67 & 90 \\
\hline & b. $>60$ & 3,33 & - & 6,67 & 10 \\
\hline \multirow{3}{*}{2.} & Jenis Kelamin $(\%)$ & & & & \\
\hline & a. Laki-Laki & 26,70 & 30,00 & 23,30 & 80 \\
\hline & b. Perempuan & 6,67 & 3,33 & 10,00 & 20 \\
\hline \multirow[t]{5}{*}{3.} & Pendidikan Formal (\%) & & & & \\
\hline & a. SD & 23,30 & 20,00 & 26,70 & 70 \\
\hline & b. SMP & - & 6,67 & 3,33 & 10 \\
\hline & c. SMA & 3,33 & 6,67 & - & 10 \\
\hline & d. PT & 6,67 & - & 3,33 & 10 \\
\hline \multirow[t]{4}{*}{4.} & Pendidikan Non Formal (\%) & & & & \\
\hline & a. Pelatihan & - & 6,67 & - & 6,67 \\
\hline & b. Penyuluhan & 10,00 & 6,67 & 10,00 & 26,67 \\
\hline & c. Tidak pernah & 23,33 & 20,00 & 23,33 & 66,66 \\
\hline \multirow[t]{5}{*}{5.} & Pekerjaan $(\%)$ & & & & \\
\hline & a. Petani (utama) & 33,33 & 26,67 & 33,33 & 93,33 \\
\hline & b. PNS (utama) & - & 3,33 & - & 3.33 \\
\hline & c. Wirahusaha (utama) & - & 3,33 & - & 3,33 \\
\hline & d. Peternak (sampingan) & 33,33 & 33,33 & 33,33 & 100 \\
\hline
\end{tabular}

Tabel 1 menunjukkan sebagian besar peternak masih pada tingkat pendidikan formal yang rendah, dimana sebanyak $70 \%$ berpendidikan SD, $10 \%$ SMP,
$10 \%$ SMA, dan $10 \%$ Perguruan Tinggi. Tingkat pendidikan responden masih tergolong rendah sehingga sulit menyerap teknologi yang diberikan. 
Cepriadi \& Edwina (2007), tingkat pendidikan yang relatif tinggi memungkinkan peternak mampu menerapkan peternakan dengan teknologi yang dimiliki. Sementara untuk pendidikan non formal, sebagian besar tidak pernah mengikuti pelatihan, penyuluhan sebanyak $66,6 \%$, mengikuti pelatihan $6,6 \%$, dan penyuluhan 26,6\%. (Tabel 1). Akibat belum adanya penyuluhan, pelatihan peternakan maka peternak hanya memelihara ternak sesuai pengetahuan peternak sendiri dan belum adanya teknologi yang lebih melalui penyuluhan atau pelatihan peternakan.
Usaha peternakan di Kecamatan Lolong Guba umumnya merupakan usaha sampingan. Terbukti melalui hasil survei bahwa, sebagian besar masyarakat mempunyai mata pencaharian utama sebagai petani yaitu $93,33 \%$, sedangkan wirausaha 3,33\%, dan PNS $3,33 \%$. Usaha peternakan merupakan usaha sampingan $100 \%$. Sehingga tidak sepenuhnya untuk pemeliharaan ternak dan manajemen pemeliharaannya pun kurang diperhatikan, hal ini berpengaruh terhadap perkembangan usaha peternakan.

Tabel 2. Karakteristik Usaha Ternak Ruminansia Di Kecamatan Lolong Guba

\begin{tabular}{|c|c|c|c|c|c|}
\hline \multirow[b]{2}{*}{ No } & \multirow[b]{2}{*}{ Uraian } & \multicolumn{3}{|c|}{ Desa } & \multirow[b]{2}{*}{$\begin{array}{l}\text { Kecamatan } \\
\text { Lolong Guba }\end{array}$} \\
\hline & & Waegeren & Grandeng & Wanakarta & \\
\hline \multirow[t]{4}{*}{1.} & Tujuan usaha (\%) & & & & \\
\hline & a. Tabungan & 26,67 & 33,33 & 26,67 & 86,67 \\
\hline & b. Sampingan & 6,67 & - & 6,67 & 13,33 \\
\hline & c. Status Sosial & - & & & 0 \\
\hline \multirow[t]{5}{*}{2.} & Kepemilikan Kandang (\%) & & & & \\
\hline & a. Memiliki kandang & 26,67 & 30,00 & 26,67 & 83,33 \\
\hline & $\begin{array}{l}\text { b. Tidak memiliki kandang } \\
\text {-Fungsi Kandang }\end{array}$ & 6,67 & 3,33 & 6,67 & 16,67 \\
\hline & a. Melindungi ternak di waktu malam & 20,00 & 23,33 & 23,33 & 66,67 \\
\hline & b. Melindungi ternak sepanjang hari & 13,33 & 10,00 & 10,00 & 33,33 \\
\hline \multirow[t]{4}{*}{3.} & Sistem Pemeliharaan (\%) & & & & \\
\hline & a. Intensif & 3,33 & 6,67 & 6,67 & 16,67 \\
\hline & b. Semi Intensif & 23,33 & 20,00 & 23,33 & 66,67 \\
\hline & a. Ekstensif & 6,67 & 6,67 & 3,33 & 16,67 \\
\hline \multirow[t]{5}{*}{4.} & Lama usaha peterak $(\%)$ & & & & \\
\hline & a. $\quad<5$ Tahun & 6,67 & 13,33 & 3,33 & 23,33 \\
\hline & b. 6-10 Tahun & 10,00 & 10,00 & 13,33 & 33,33 \\
\hline & c. $11-15$ Tahun & 13,33 & 6,67 & 6,67 & 26,67 \\
\hline & d. $>15$ Tahun & 3,33 & 3,33 & 10,00 & 16,63 \\
\hline \multirow[t]{4}{*}{5.} & Jenis ternak $(\%)$ & & & & \\
\hline & a. Sapi & 30,00 & 26,67 & 30,00 & 86,67 \\
\hline & b. Kerbau & 3,33 & - & 3,33 & 6,66 \\
\hline & c. Sapi dan kambing & - & 6,67 & - & 6,67 \\
\hline \multirow[t]{4}{*}{6.} & JumlahTernak (UT) & & & & \\
\hline & a. $<5$ ekor & 13,33 & 6,67 & 3,33 & 23,33 \\
\hline & b. 5- 10 ekor & 20,00 & 23,33 & 20,00 & 63,33 \\
\hline & c. $>10$ ekor & - & 3,33 & 10,00 & 13,33 \\
\hline
\end{tabular}

\section{Usaha Ternak}

Hasil survei menunjukkan bahwa tujuan pemeliharaan ternak ruminansia adalah sebagai tabungan $86,6 \%$, sisanya sebagai sampingan $13,33 \%$. Sebagian besar petani peternak hanya memelihara ternak sebagai tabungan apabila terdapat kebutuhan penting atau sangat membutuhkan baru dijual. Dari aspek perkandangan, petani peternak yang memiliki kandang 83,33\% , sedangkan 16,6\% tidak memiliki kandang, dengan fungsi kandang hanya sebagai tempat untuk melindungi ternak di waktu malam 66,67\% dan melindungi ternak sepanjang hari 16,67 \%. Hasil survey menunjukkan bahwa sistem pemeliharaan ternak ruminansia di Kecamatan Lolong Guba sebagian besar secara semi intensif $66,67 \%$, intensif $16,67 \%$, dan masih dilakukan sistem pemeliharaan ekstensif 16,67\% (Tabel 2). Hasil wawancara dengan peternak diketahui bahwa sistem pemeliharaan semi intensif tidak membutuhkan waktu yang relatif banyak untuk menangani ternak dimana hanya dengan cara pagi hari ternak dikeluarkan dari kandang, kemudian diikat di padang penggembalaan dan sore hari baru dimasukkan kembali ke dalam kandang dan diberi pakan tambahan.

Tingkat pengalaman peternak tergantung dengan lama usaha beternak. Hasil penelitian menunjukkan lama usaha bervariasi dimana sebesar $23,33 \%$ peternak dengan lama usaha kurang dari 5 
tahun, 33,33\% peternak dengan lama usaha $6-10$ tahun, 26,67\% peternak dengan lama usaha 11-15 tahun, dan $16,63 \%$ peternak dengan lama usaha lebih dari 15 tahun. Lama usaha merupakan pengalaman beternak sangat berpengaruh terhadap tingkat pengetahuan dan keterampilan peternak dalam mengelola ternak sebagai usaha sampingan. Umumnya pengalaman beternak diperoleh dari orang tua secara turun-temurun, karena pengalaman dapat dijadikan pedoman dan penyesuaian terhadap permasalahan usaha ternak di masa mendatang. Juliawati (2013), semakin lama pengalaman beternak, cenderung semakin mempermudah peternak dalam penggambilan keputusan yang berhubungan dengan teknis pelaksanaan usaha. Pengalaman dapat dijadikan pedoman dan penyesuaian terhadap permasalahan usaha ternak masa mendatang.
Hasil survey menunjukkan bahwa jenis ternak yang diusahakan sebagian besar ternak sapi 86,66 \%, kambing 6,67 \%, dan ternak kerbau 6,67\%, diduga karena pemeliharaan ternak sapi lebih mudah dipelihara dan banyak diminati oleh pedagang atau pengepul, selain itu keuntungan yang diperoleh juga lebih besar. Jumlah ternak yang dipelihara juga bervariasi, peternak yang memiliki jumlah ternak terbanyak 5- 10 ekor sebesar 63,33\%, < 5 ekor sebesar 23,33\%, dan > 10 ekor sebesar 13,33\%. Di kecamatan Lolong Guba yang memiliki usaha ternak rumminansia hanya sebagai sampingan (berskala kecil) ini terlihat bahwa skala kepemilikan ternak di kecamatan Lolong Guba lebih besar dari skala kepemilikan sapi pada peternak rakyat menurut Fariani dkk. (2014), hal ini berarti sekala kepemilikan sapi pada peternak rakyat hanya berkisar 2-5 ekor.

Tabel 3. Pakan dan Lahan Pengembalaan Ternak Ruminansia Di Kecamatan Lolong Guba

\begin{tabular}{|c|c|c|c|c|c|}
\hline No & Uraian & $\begin{array}{c}\text { Desa } \\
\text { Waegeren }\end{array}$ & $\begin{array}{c}\text { Desa } \\
\text { Grandeng }\end{array}$ & $\begin{array}{c}\text { Desa } \\
\text { Wanakarta }\end{array}$ & $\begin{array}{c}\text { Kecamatan } \\
\text { Lolong Guba }\end{array}$ \\
\hline \multirow[t]{3}{*}{1.} & 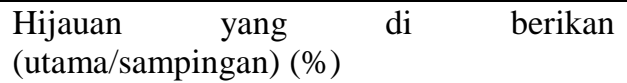 & & & & \\
\hline & a. Rumput (utama) & 33,33 & 33,33 & 33,33 & 100 \\
\hline & b. Limbah pertanian (sampingan) & 33,33 & 33,33 & 33,33 & 100 \\
\hline \multirow[t]{3}{*}{2} & Sumber Pakan $(\%)$ & & & & \\
\hline & a. Rumput lapangan ( utama) & 33,33 & 33,33 & 33,33 & 100 \\
\hline & b. Rumput unggul (tambahan) & 20,00 & 23,33 & 23,33 & 66.66 \\
\hline \multirow[t]{4}{*}{3.} & Tempat Pengembalaan (\%) & & & & \\
\hline & a. Padang rumput & 16,67 & 16,67 & 16,67 & 50,01 \\
\hline & b. Pinggir jalan & - & 6,67 & 10,00 & 16,67 \\
\hline & c. Di Sawah & 16,67 & 10,00 & 6,67 & 33,33 \\
\hline \multirow[t]{4}{*}{4.} & Pakan Tambahan (konsentrat) (\%) & & & & \\
\hline & a. Dedak & 20,00 & 20,00 & 16,67 & 56,67 \\
\hline & b. AmpasTahu & - & - & 4,00 & 4,00 \\
\hline & c. Garam & 10,00 & 10,00 & 6,67 & 26,67 \\
\hline \multirow[t]{4}{*}{5.} & Kepemilikan Lahan (\%) & & & & \\
\hline & a. Milik sendiri & 23,33 & 20,00 & 16,67 & 60,00 \\
\hline & b. Orang lain & 6,67 & 10,00 & 3,33 & 20,00 \\
\hline & c. Milik desa/digunaka untuk umum & 3,33 & 3,33 & 13,33 & 19,99 \\
\hline \multirow[t]{4}{*}{6.} & $\begin{array}{l}\text { Jenis Tempat usaha pertanian tanaman } \\
\text { pangan }(\%)\end{array}$ & & & & \\
\hline & a. Sawah & 26,67 & 23,33 & 16,67 & 66,67 \\
\hline & b. Kebun & 3,33 & 10,00 & 10,00 & 23,33 \\
\hline & c. Sawah dan kebun & 3,33 & - & 6,67 & 10 \\
\hline \multirow[t]{7}{*}{7.} & Luas lahan (\%) & & & & \\
\hline & a. $1 / 4$ & 3,33 & 3,33 & 3,33 & 10 \\
\hline & b. $<0,5$ & - & 6,67 & 3,33 & 10 \\
\hline & c. 1 & 20,00 & 20,00 & 13,33 & 53,33 \\
\hline & d. 2 & 6,67 & - & 6,67 & 13,34 \\
\hline & e. 2,5 & - & - & 3,33 & 6,67 \\
\hline & f. $>3$ & 3,33 & 3,33 & 3,33 & 9,99 \\
\hline
\end{tabular}

\section{Pakan Ternak Ruminansia}

Pemberian pakan untuk ternak ruminansia yang biasa dilakukan oleh petani peternak di Kecamatan Lolong Guba seperti tertera pada Tabel 3. Hasil survey menunjukkan sumber pakan pokok untuk ternak ruminansia yang dipelihara, biasanya diberikan rumput lapangan $100 \%$, dan sebagai pakan tambahan yaitu rumput unggul $66,67 \%$. Hal ini dikarenakan 
pemberian rumput lapangan lebih mudah didapat, sedangkan rumput unggul harus melalui proses penanaman dan membutuhkan waktu yang lama, karena hampir seluruh waktunya petani peternak di gunakan untuk bertani.

Hasil penelitian memperlihatkan semua peternak memberikan rumput untuk ternak sebagai pakan pokok yaitu sebesar $100 \%$ (baik rumput potong maupun rumput lapangan), selain itu juga memberikan limbah pertanian sebagai pakan sampingan atau pakan tambahan sebesar $100 \%$, hal ini terutama dilakukan pada saat musim panen. Menurut de Lima dan Yoris (2009), pola penggembangan limbah pertanian dalam ransum ternak kelihatannya mengikuti pola tanaman yang ada di daerah bersangkutan. Limbah pertanian dimanfaatkan sebagai pakan ternak tambahan/sampingan agar limbah tidak terbuang begitu saja, maka petani di Kecamatan Lolong Guba memanfaatkannya sebagai pakan ternak terutama pada musim panen. Hal ini juga disebabkan karena Kecamatan Lolong Guba, pada sektor pertanian memberikan kontribusi cukup besar sebagai sumber pendapatan keluarga. Sektor ini terbagi menjadi sub sektor tanaman pangan, tanaman holtikultura, dan tanaman perkebunan yang tentunya menghasilkan potensi biomasa yang cukup besar sebagai sumber pakan lokal bagi pengembangan ternak ruminansia di Kecamatan Lolong Guba. Selain itu petani peternak memberikan pakan tambahan konsentrat berupa dedak sebesar $64 \%$, ampas tahu $4 \%$, dan garam $32 \%$, yang diberikan dengan kombinasi rumput dan limbah pertanian untuk menambah nafsu makan ternak.

Hal penelitian menunjukkan bahwa petani peternak sebagian besar menggembalakan ternak di padang rumput $50 \%$, di pinggir jalan $16,67 \%$, dan di sawah setelah panen $33,33 \%$. Kepemilikan lahan yang digunakan sebagai tempat gembala $60 \%$ memiliki lahan sendiri, dan sengaja dibiarkan tumbuh rumput liar di area tersebut dengan tujuan untuk dijadikan sebagai padang rumput yang digunakan untuk menggembalakan ternaknya, sedangkan milik orang lain sebesar 16,67\%, dan lahan milik desa untuk mengembalakan ternak sebesar 23,33\%. Ini berarti bahwa masyarakat yang bermata pencaharian bertani tidak terlepas dari usaha ternak sapi. Juliawati (2013), lahan merupakan suatu potensi yang dimiliki oleh seorang petani sebagai sumber pakan bagi ternaknya dapat berupa rumput, limbah atau produk utama pertanian. Petani peternak memiliki lahan tempat usaha pertanian tanaman pangan di sawah $66,6 \%$, di lahan kebun 23,33 \%, sedangkan usaha di sawah dan kebun $10 \%$. Luas lahan usaha yang dimiliki bervariasi, dimana $10 \%$ petani peternak memiliki luas lahan pertanian $1 / 4$ ha , $10 \%$ memiliki luas lahan pertanian kurang dari 0,5 ha, 53,33\% memiliki luas lahan pertanian 1 ha, 13,34\% memiliki luas lahan pertanian 2 ha, 6,67\% memiliki luas lahan pertanian 2,5 ha, dan 9,9\% memiliki luas lahan pertanian lebih dari 3 ha. Besar kecilnya luas lahan usaha petanian tanaman pangan yang diolah akan mempengaruhi terhadap ketersediaan limbah pertanian tanaman pangan sebagai pakan ternak ruminansia sebagai pakan utama maupun pakan tambahan.

\section{Pemanfaatan Limbah Pertanian Sebagai Pakan Ternak Ruminansia}

Faktor-faktor yang menyebabkan peternak tidak menggunakan limbah pertanian tanaman sebagai pakan ternak diantaranya adalah a) umumnya petani membakar limbah karena secepatnya akan dilakukan pengolahan tanah, b) limbah pertanian bersifat kamba sehingga menyulitkan untuk mengangkut dan memerlukan tenaga dan waktu karena jauh dari lokasi pengembalaan dan rumah peternak, c) tidak tersedia tempat penyimpanan, dan d) peternak menganggap bahwa ketersediaan hijauan di lahan kebun dan tempat penggembalaan masih mencukupi sebagai pakan ternak (Febrina \& Liana, 2008).

Hasil penelitian seperti tertera pada Tabel 4 menunjukkan bahwa petani peternak telah memanfaatkan limbah pertanian sebagai pakan ternak $100 \%$, walaupun dianggap hanya sebagai pakan tambahan. Jerami yang dimanfaatkan sebagai pakan ternak yaitu jerami jagung $16,67 \%$, jerami padi $43,33 \%$, jerami ketela pohon 6,67\%, dan jerami ketela rambat 33,33 \%. Sudaryanto (2013), menyatakan bahwa usaha ternak sapi akan efisisen jika manajemen pemeliharaan diintegrasikan dengan tanaman sebagai sumber pakan itu sendiri dan ternak dapat menghasilkan pupuk untuk meningkatkan produksi tanaman. Jerami yang dimanfaatkan dan dijadikan sebagai makanan ternak di Kecamatan Lolong Guba adalah jerami padi (Oryza sativa), jerami jagung (Zea mays), jerami ketelah pohon (Manihot utilisima), dan ketelah rambat, yang diberikan pada saat panen setelah diambil hasil utamanya, sedangkan hasil ikutan pertanian yang dimanfaatkan sebagai pakan tambahan berupa dedak padi dan ampas tahu.

Pemanfaatan limbah pertanian sebagai pakan ternak ruminansia oleh peternak di Kecamatan Lolong Guba adalah sebagai berikut dedak padi $64 \%$, sedangkan ampas tahu hanya $4 \%$. Tingginya tingkat pemanfaatan limbah pertanian sebagai pakan disebabkan karena peternak segera memberikan (jerami padi, jagung, ubi jalar dan ketela pohon) setelah panen, meskipun dalam kondisi hijauan pakan tersedia dalam jumlah yang mencukupi di lahan padang pengembalaan, sawah, dan kebun untuk kebutuhan ternak. Syamsu dkk. (2003), melaporkan bahwa hanya $37,88 \%$ peternak di Sulawesi Selatan yang menggunakan limbah pertanian sebagai pakan. Produksi limbah pertanian mempunyai potensi yang cukup besar untuk memenuhi kebutuhan ternak akan pakan hijauan. Hal ini di dukung oleh Haryanto (2003), yang menyatakan bahwa jerami sebagai sisa hasil pertanian merupakan sumber utama bagi pakan ternak ruminansia, di beberapa daerah terutama pada musim kemarau. 
Tabel 4.Pemanfaatan Limbah pertanian Sebagai Pakan Sampingan

\begin{tabular}{|c|c|c|c|c|c|}
\hline No & Uraian & $\begin{array}{c}\text { Desa } \\
\text { Waegeren }\end{array}$ & $\begin{array}{c}\text { Desa } \\
\text { Grandeng }\end{array}$ & $\begin{array}{c}\text { Desa } \\
\text { Wanakarta }\end{array}$ & $\begin{array}{l}\text { Kecamatan } \\
\text { Lolong Guba }\end{array}$ \\
\hline \multirow[t]{3}{*}{1.} & Penggunaan limbah sebagai pakan (\%) & & & & \\
\hline & Ya & 33,33 & 33,33 & 33,33 & 100 \\
\hline & Tidak & - & - & - & 0 \\
\hline \multirow[t]{5}{*}{2.} & Jenis limbah pertanian (\%) & & & & \\
\hline & a. Jerami jagung & 3,33 & 6,67 & 6,67 & 16,67 \\
\hline & Jerami padi & 16,67 & 13,33 & 13,33 & 43,33 \\
\hline & Jerami ketela pohon & 3,33 & - & 3,33 & 6,66 \\
\hline & Jerami ketela rambat & 10,00 & 13,33 & 10 & 33,33 \\
\hline \multirow[t]{3}{*}{3.} & Cara pengolahan limbah (\%) & & & & \\
\hline & Langsung di beri & 33,33 & 930,00 & 30,00 & 93,33 \\
\hline & Pengolahan & - & 3,33 & 3,33 & 6,66 \\
\hline \multirow[t]{3}{*}{4.} & Mengetahui tingkat pengolahan (\%) & & & & \\
\hline & Ya & - & 3,33 & 3,33 & 6,66 \\
\hline & Tidak & 33,33 & 30,00 & 30,00 & 93,33 \\
\hline 5. & $\begin{array}{l}\text { Waktu Pemberian (\%) } \\
\text { pada saat musim panen ( musim hujan } \\
\text { atau musim kemarau) }\end{array}$ & 33,33 & 33,33 & 33,33 & 100 \\
\hline
\end{tabular}

Hasil penelitian menunjukkan bahwa pemberian limbah yang diberikan secara langsung untuk ternak tanpa adanya pengolahan persentasenya sebesar 93,33 $\%$, sedangkan 6,67 \% dilakukan pengolahan sebelum diberikan untuk ternak, terutama pengolahan jerami padi sebagai pakan ternak. Hal ini diduga disebabkan karena petani belum mengetahui dan memahami teknik pengolahan jerami sebagai pakan ternak. Hasil penelitian menunjukkan bahwa $93,33 \%$ petani tidak mengetahui tingkat pengolahan limbah pertanian. Syamsu (2011), berhubungan dengan teknologi pakan limbah, tingkat penerapan teknologi pakan sangat rendah. Kurangnya jumlah peternak yang melakukan teknologi pakan atau tingkat penerapan rendah disebabkan oleh beberapa faktor yaitu a) teknologi pakan dianggap tidak efektif untuk dilaksanakan karena membutuhkan curahan waktu (menghabiskan waktu), seperti dalam mengumpulkan dan mengangkut limbah, serta dalam proses pembuatannya. Sementara waktu mereka lebih banyak tercurah pada usaha tani. Hal ini disebabkan karena usaha ternak masih dianggap sebagai usaha sambilan sehingga perhatiaan dan curahan waktu berkurang ; b) teknologi pakan dalam penerapannya membutuhkan bahan dan alat, seperti dalam amoniasi dan silase membutuhkan tempat untuk penyimpanan, atau bahan lain seperti penambahan urea yang memberikan konsekuensi adanya penambahan biayanya ; dan c) peternak kurang memahami bahwa teknologi pakan dapat meningkatkan kualitas limbah sebagai pakan sehingga dapat meningkatkan produktivitas ternak. Haryanto (2003), jerami padi merupakan limbah hasil pertanian yang sangat potensial untuk dimanfaatkan sebagai pakan ternak. Namun demikian, pemanfaatan jerami padi sebagai pakan ternak belum optimal karena rendahnya kandungan protein kasar (3-4 \%), dan tinggi kandungan serat kasar (32-40\%) sehingga memiliki tingkat kecernaan yang rendah yaitu berkisar 35-37\% .

\section{SIMPULAN DAN REKOMENDASI}

Berdasarkan data hasil dan pembahasan, maka dapat disimpulkan : (a) pada umumnya peternak di Kecamatan Lolong Guba memelihara ternak hanya sebagai tabungan dan sistem pemeliharaannya bersifat semi intensif ; (b) jenis limbah pertanian yang dimanfaatkan sebagai pakan ternak ruminansia adalah jerami padi, jerami jagung, jerami ketelah pohon, dan jerami ketela rambat, serta penggunaannya terutama tergantung musim panen, dan (c) penggunaan limbah pertanian sebagai pakan ternak adalah sebesar 93,3\% diberikan secara langsung setelah panen tanpa melalui pengolahan.

Rekomendasi yang dapat dikemukakan berdasarkan hasil penelitian diantaranya (a) untuk mempertahankan dan meningkatkan kualitas limbah pertanian sebaiknya dilakukan pengolahan seperti pembuatan silase atau hay, dan (b) perlu adanya penyuluhan dan pelatihan berkelanjutan untuk meningkatkan pengetahuan petani peternak sehingga dapat mengaplikasikan pemanfaatan limbah dan pengolahan limbah pertanian sebagai pakan ternak ruminansia.

\section{DAFTAR PUSTAKA}

[BPS] Badan Pusat Statistik Kabupaten Buru. 2017. Kecamatan Lolong Guba Dalam Angka Tahun 2017. Namlea: Badan Pusat Statistik Kabupaten Buru. 
Bodhi, A., M. Lamid, A. Maruf, \& M. T. E. Purnama. 2017. Identifikasi Limbah Pertanian Dan Perkebunan Sebagai Bahan Pakan Inkonvesional Di Banyuwangi. Jurnal Medik Veteriner. 1(1): 12-22. DOI: http://dx.doi.org/10.20473/ jmv.vol1.iss 1.2017.12-22.

Cepriadi, \& S. Edwina. 2007. Analisis Usaha Peternakan Ayam Broiler Pola Kemitraan Di Kota Pekan Baru. Jurnal Peternakan. 4(1): 2029.

de lima, D. 2012. Produksi Limbah Pertanian dan Limbah peternakan Serta Pemanfaatannya. Jurnal Agroforestri. 7(1): 18-22.

de Lima, D., \& L. Yoris. 2009. Potensi Pengembangan Peternakan Maluku Dalam Mendukung Ketahanan Pangan Nasional. Prosiding Seminar Nasional Jurusan Peternakan Fakultas Pertanian Unpatti. Ambon, 2 Maret 2009. p. 94 $-104$.

Fariani, A., S. Susantina, \& Muhakka. 2014. Pengembangan Populasi Ternak Ruminansia Berdasarkan Ketersediaan Lahan Hijauan dan Tenaga Kerja di Kabupaten Ogan Komering Ulu Timur Sumatra Selatan. Jurnal Peternakan Sriwijaya. 3(1): 37-46.

Febrina, D., \& M. Liana. 2008. Pemanfaatan Limbah Pertanian Sebagai Pakan Ruminansia pada Peternak Rakyat Di Kecamatan Rengat Barat Kabupaten Indragiri Hulu. Jurnal Peternakan. 5(1): 28-37. DOI: http://dx.doi.org/10.24014/jupet.v5i1.282.

Hartono, B. 2005. Curahan Tenaga Kerja Keluarga Di Usaha Ternak Sapi Kasus di Desa Pandansari Kecamatan Pujon Kabupaten Malang. Buletin Peternakan. 29(3): 131-138. DOI: .https://doi.org/10.21059/ buletinpeternak.v29i3.1180.

Haryanto, B. 2003. Jerami Padi Fermentasi Sebagai Ransum Dasar Ternak Ruminansia. Warta Litbang Pertanian. 25(3): 1-3.

Haryanto, B. 2009. Inovasi Teknologi Pakan Ternak Dalam Sistem Integrasi Tanaman-Ternak Bebas Limbah Mendukung Upaya Peningkatan Produksi Daging. J. Pengembangan Inovasi Pertanian. 2 (3): 163-176.
Juliawati. 2013. Potensi Limbah Tanaman Pangan Sebagai Sumber Pakan Dalam Pengembangan Ternak Sapi Potong Di Provinsi Sulawesi Barat. Mamuju: Dinas Pertanian Dan Peternakan Provinsi Sulawesi Barat.

Parakkasi, A. 1999. Ilmu Nutrisi dan Makanan Ternak Ruminansia. Jakarta: Universitas Indonesia Press.

Rauf, J., \& Rasbawati. 2015. Kajian Potensi Limbah Pertanian Sebagai Pakan Ternak Sapi Potong Di Kota Pare-Pare. Jurnal Galung Tropika. 4(3): 173-178.

DOI: http://dx.doi.org/10.31850/jgt.v4i3.121.

Sari, A., Liman, \& Muhtarudin. 2016. Potensi Daya Dukung Limbah Tanaman Palawija Sebagai Pakan Ternak Ruminansia Di Kabupaten Pringsewu. Jurnal Ilmiah Peternakan Terpadu. 4(2): 100-107. DOI: http://dx.doi.org/10.23960/jipt.v4i2.p\%25 p.

Simanjuntak, P. J. 2001. Ekonomi Sumberdaya Manusia. Jakarta: Lembaga Penerbit Fakultas Ekonomi Universitas Indonesia.

Sitindaon, S. H. 2013. Inventarisasi Potensi Bahan Pakan Ternak Ruminansia Di Provinsi Riau. Jurnal Peternakan. 10(1): 18-23.

Sudaryanto, B. 2013. Pemanfaatan Limbah Pertanian Sebagai Bahan Pakan Ternak Ruminansia. J. Pengembanggan Inovasi Pertanian. 6(3): 130138.

DOI: http://dx.doi.org/10.21082/pip.v6n3.2013.130138.

Sumarsono, S. 2003. Ekonomi Manajemen Sumberdaya Manusia dan Ketenagakerjaan. Yokyakarta: Graha Ilmu.

Syamsu, J. A., L. A. Sofyan, K. Mudikdjo, \& G. Said. 2003. Daya Dukung Limbah Pertanian Sebagai Sumber Pakan Ternak Ruminansia di Indonesia. Wartazoa. 13(1): $30-37$.

Syamsu, J. A. 2011. Reposisi Paradigma Pengembangan Peternakan Pemikiran, Gagasan Dan Perencanaan Public. Yogyakarta: Absolut Media. 